\title{
Pengembangan Media Gunungan Pada Pembelajaran Tematik Tema Permainan Tradisional
}

\author{
Emy Marfuatin ${ }^{*}$, M. Yusuf Setia W², Aries Tika Damayani ${ }^{3}$ \\ ${ }^{123}$ PGSD FIP Universitas PGRI Semarang
}

\begin{abstract}
Abstrak
Penelitian ini dilatar belakangi oleh proses penyampaian pembelajaran yang belum menggunakan media tematik dan sehingga siswa kurang tertarik, saat istirahat siswa bermaian lari-larian sehingga saat mulai pembelajaran daya konsetrasi siswa

Keywords:

Pengembangan, Media Gunungan sudah banyak yang menurun dan masih ingin bermain-main. Penelitian ini dilaksanakan di kelas III A dan III B yaitu di 2 SD N Tompomulyo 02 yang berada di ruang lingkup Desa Tompomulyo Kecamatan Batangan Kabupaten Pati. Subjek penelitian ini terdiri dari kelas III A dan III B di SD N Tompomulyo 02 Desa Tompomulyo Kecamatan Batangan Kabupaten Pati sebagai kelas uji coba produk dengan jumlah responden 19 siswa di kelas III A dan 18 siswa kelas III B SD N Tompomulyo 02. Penelitian ini menggunakan metodologi penelitian dan pengembangan (RnD) yang digunakan untuk menghasilkan produk tertentu dan menguji kelayakan produk yang dikembangkan. Kesimpulan dari penelitian ini adalah dihasilkan media gunungan tema 5 permainan tradisional subtema 2 permainan tradisional kelas III sekolah dasar dilengkapi dengan soal ketika menggunakan media pembelajaran. Media dikatakan layak sesuai dengan hasil angket respon guru kelas mendapatkan persentase skor total sebesar 97,82\% dengan kriteria sangat layak dan hasil angket respon siswa mendapatkan persentase skor total sebesar 98,88\% dengan kriteria sangat layak. Serta untuk tambahan pengetahuan bahwa media ini benar-benar layak peneliti juga menilai aspek sikap autentik aspek sikap skor total 87,15\%, aspek pengetahuan skor 89,06\%, dan aspek ketrampilan skor 89,39\%. Sehingga pada pada saat proses pembelajaran berlangsung, media gunungan dapat membuat siswa belajar secara menyenangkan karena dapat belajar sambil bermain di dalam kelas.
\end{abstract}

\section{PENDAHULUAN}

Belajar merupakan sebuah proses yang kompleks yang terjadi pada semua orang dan berlangsung seumur hidup, sejak masih bayi (bahkan dalam kandungan) hingga liang lahat. Salah satu pertanda bahwa seseorang telah belajar sesuatu adalah adanya perubahan tingkah laku dalam dirinya. Perubahan tingkah laku tersebut menyangkut perubahan yang menyangkut perubahan yang bersifat Pengetahuan (kognitif) dan keterampilan (psikomotor) maupun yang menyangkut nilai dan sikap (afektif). (Nara, 2014:3)

Pendidikan mempunyai peranan penting dalam kehidupan, melalui pendidikan seorang dapat mengembangkan potensi yang diiliki dalam dirinya. Menurut Undang-Undang No. 20 Tahun 2003 Pendidikan Nasional berfungsi mengembangkan kemampuan dan membentuk watak serta peradaban bangsa yang bermartabat dalam rangka mencerdaskan kehidupan bangsa. Untuk itu pendidikan nasional bertujuan untuk mengembangkan potensi peserta didik agar menjadi manusia yang beriman dan bertakwa kepada Tuhan Yang Maha Esa, berakhlak mulia, sehat, berilmu, cakap, kreatif, mandiri, dan menjadi warga Negara yang demokratis serta bertanggung jawab. Kata media berasal dari bahasa latin medius yang secara harfiah berarti "tengah", "Perantara”, atau "pengantar". Dalam Bahasa Arab, media adalah perantara atau pengantar pesan dari pengirim kepada penerima pesan. (Azar Arsyad, 2014:3).

* Corresponding author.

E-mail Addresses: - emymarfuatin01@gmail.com (Emy Marfuatin) 
Pendidikan yang baik adalah pendidikan yang mengikuti perkembangan kurikulum. Karena, dalam suatu system pendidikan, kurikulum itu sifatnya dinamis serta harus selalu dilakukan perubahan dan pengembangan agar dapat mengikuti perkembangan dan tantangan zaman. Meskipun demikian, perubahan dan pengembangan harus dilakukan secara sistematis dan terarah, tidak asal berubah. (Mulyasa, 2013:59).

Pendidikan saat ini, banyak sekali menghadapi masalah. Diantaranya adalah pemahaman guru untuk mengerti cara belajar siswa untuk lebih tertarik dalam pembelajaran dan Selain Kurikulum, Untuk menciptakan pendidikan yang baik dan bisa meningkatkan rasa tertaik siswa tentu harus ada fasilitas yang baik sebagai penunjang pembelajaran dan membantu dalam proses pembelajaran di kelas. Salah satu fasilitas tersebut adalah media pembelajaran. Karena media pembelajaran dapat membantu guru dan siswa dalam belajar. Media pembelajaran yang digunakan tidak harus mahal ataupun rumit. Namun, dengan media yang sederhana juga bisa membuat suasana belajar lebih menyenangkan sehingga siswa bisa tertarik untuk mengikuti dan memperhatikan pembelajaran.

Pendidikan adalah salah satu kebutuhan yang paling penting bagi manusia, terutama untuk anak usia sekolah khususnya anak usia sekolah dasar. Karena pada usia sekolah dasar ini anak-anak memiliki rasa ingin tahu yang tinggi serta lebih bisa mengingat segala hal dalam jangka waktu yang lama. Dan di sekolah dasar khususnya kelas rendah, siswa masih terbawa suasana bermain . dan ketika siswa kelas rendah di ajak untuk berfikir serius, maka siswa akan lebih cepat bosan. Dari karakter siswa kelas rendah yang mudah bosan dan masih cenderung suka bermain-main tersebut, maka peneliti berinisiatif menggunakan media pembelajaran yang berdasarkan pada permainan dalam proses pembelajaran. Permainan yang digunakan oleh peneliti juga permainan yang tidak asing bagi para siswa, khususnya siswa di daerah pedesaan. Dan permainan tersebut adalah permainan tradisional yang dikembangkan semenarik mungkin untuk lebih membuat siswa tidak jenuh. Permainan tradisional tersebut salah satunya adalah gunungan.

Dalam suatu pendidikan, kurikulum itu sifatnya dinamis serta harus selalu dilakukan perubahan dan pengembangan, agar dapat menikuti perkembangan dan tantangan zaman. Meskipun demikian, perubahan dan pengembanganya harus dilakukan secara sistematis dan terarah, tidak asal berubah. Perubahan dan pengembangan kurikulum tersebut harus memiliki visi dan arah yang jelas, mau dibawa kemana system pendidikan nasional dengan kurikulum tersebut. (Mulyasa, 2016:59)

Melalui adanya pengembangan kurikulum, maka pembelajaran akan lebih produktif, inovatif, dan aktif. Karena dalam kurikulum sekarang yaitu kurikulum 2013 bukan hanya pengetahuannya saja yang dinilai, namun juga sikap dan keterampilan juga dinilai. "Beberapa aspek atau ranah yang terkandung dalam konsep kompetensi yaitu : Pengetahuan (knowledge), Pemahaman (Understanding), Kemampuan (skill), Nilai (value), Sikap (attitude), dan Minat (interest)". (Mulyasa, 2016:65)

Pelaksanaan kurikulum 2013 ditandai dengan adanya pembelajaran tematik integratif kelas 1 sampai dengan kelas 6. Berdasarkan hasil observasi dan wawancara dengan guru kelas III A Ibu Siti Fatimah dan Kelas III B Retno Jumilah, S.Pd Sekolah Dasar Negeri Tompomulyo 02 bahwa karakteristik siswa SD senang bermain-main dengan temannya di dalam kelas. Anak SD syarat dengan bermain, sehingga ketika memasuki kelas dan guru dalam mengajarkan materi tidak dengan media , maka siswa akan mudah jenuh dan siswa akan bosan sehingga siswa tidak memperhatikan penjelasan dari guru bahkan siswa akan berbicara dengan teman sebangkunya sendiri. Permainan anak pada kurun waktu ini, sangat terbatas pada permainan gadget. Salah satu permainan yang bisa membuat anak lebih antusias dalam pembelajaran adalah permainan tradisional. Salah satu permainan tradisional yang bisa digunakan adalah permainan tradisional gunungan. Permainan gunungan ini bisa dimainkan oleh anak laki-laki maupun anak perempuan. Permainan ini juga mudah dibuat, hanya dengan menggambar dengan batu atau kapur untuk membuat garisnya, dan tiap pemain hanya memegang sepotong pecahan genting atau batu.

Berdasarkan pengalaman ketika melakukan wawancara dan melakukan penyebaran angket kebutuhan peserta didik kelas III SD N Tompomulyo 02 peneliti mengetahui bahwa sekolah memerlukan pengembangan media yang lebih menarik dan lebih praktis digunakan pada saat pembelajaran.

Dari permasalahan yang diperoleh dari pengumplan data di sekolahpeneliti mengembangkan permainan gunungan menjadi media pembelajaran berbasis permainan. Dalam hal ini permainan gunungan yang dipadukan dengan pembelajaran tematik tema permainan tradisional, sub tema permainan tradisional. Kompetensi Dasar yang digunakan dalam pengembangan media antara lain materi permainan tradisional, materi sikap bersatu dalam keberagaman, dan materi konsep gerak non lokomotor.

Berdasarkan latar belakang diatas maka di rumusan masalah penelitian adalah Bagaimanakah pengembangan media gunungan pada pembelajaran tematik tema permainan tradisional di kelas III Sekolah Dasar, dan apakah pengembangan media gunungan praktis digunakan pada pembelajaran 
tematik tema permainan tradisional di kelas III Sekolah Dasar. Tujuan penelitian ini yaitu bertujuan untuk Untuk mengembangkan media gunungan pada pembelajaran tematik tema permainan tradisional di kelas III Sekolah Dasar, serta Untuk mengetahui kepraktisan media gunungan pada pembelajaran tematik tema permainan tradisional di kelas III Sekolah Dasar. Adanya Media Gunungan ini maka dapat melengkapi komponen pendidikan untuk membantu proses pembelajaran yang dilakukan guru dengan siswa dan tercapainya proses pendidikan.

\section{METODE PENELITIAN}

Jenis Penelitian metode Jenis penelitian yang digunakan adalah Penelitian dan Pengembangan atau Research and Development (R\&D). Sugiyono (2018:297) mengatakan bahwa metode penelitian dan pengembangan atau dalam bahasa inggrisnya Research and Development adalah metode penelitian yang digunakan untuk menghasilkan produk tertentu, dan menguji kebutuhan produk tersebut. Untuk menghasilkan produk tertentu digunakan penelitian yang bersifat analisis kebutuhan dan untuk menguji kebutuhan produk tersebut supaya dapat berfungsi di masyarakat luas. Langkah-langkah proses penelitian dan pengembangan ada 10 langkah yaitu Research and Information Collecting (Penelitian dan pengumpulan data), Planning (Perencanaan), Develop Preliminary form of product (pengembangan draf produk), Preliminary field testing (Uji coba lapangan awal), Main product Revision (Merevisi hasil uji coba), main field testing (uji coba lapangan), operasional product revision (penyempurnaan produk hasil uji lapangan), operasional field testing (uji pelaksanaan lapangan), final product revision (penyempurnaan produk akhir), dan Dissemination and implementation (diseminasi dan implementasi). Namun karena ada keterbatasan waktu dan biaya dalam penelitian, maka penelitian ini hanya menggunakan 5 langkah saja, yaitu Research and Information Collecting (Penelitian dan pengumpulan data), Planning (Perencanaan), Develop Preliminary form of product (pengembangan draf produk), Preliminary field testing (Uji coba lapangan awal), Main product Revision (Merevisi hasil uji coba). Sesuai dengan langkah-langkah tersebut, maka penelitian ini diiawali dengan penelitian dan pengumpulan data, perencanaan, pengembangan draf produk, uji coba lapangan awal, dan merevisi hasil uji coba. Pengumpulan data diawali dengan permasalahan melalui observasi, wawancara dan menyebar angket kebutuhan siswa dan guru, kemudian mengumpulkan data-data yang diperlukan. Penelitian dan pengumpulan data atau informasi awal ini bisa dilakukan melalui pengamatan, observasi kelas serta dapat menggunakan menggunakan analisis kebutuhan awal berupa angket. hal ini dilakukan guna memperoleh informasi awal untuk melakukan pengembangan. hal ini dapat dilakukan misalnya dengan melalui pengamatan kelas untuk melihat kondisi yang sebenarnya di lapangan. Instrumen angket menggunakan skala Likert. Skala Likert digunakan pada angket pengujian media gunungan untuk uji validasi ahli media, uji validasi ahli materi, uji angket respon guru kelas, dan uji angket respon siswa. Penelitian dengan menggunakan skala Likert yaitu dengan menghadirkan sejumlah pernyataan yang positif dan negatif dalam suatu obyek. Dalam menjawab butir-butir pertanyaan dan dapat dipilih jawaban yang meliputi "5(sangat baik)", "4(baik)", "3(cukup)", "2(kurang)" dan "1( sangat kurang)". Juga menggunakan skala Gautama hanya memiliki dua interval saja, yaitu "setuju" dan "tidak setuju".

Data yang telah terkumpul kemudian dianalisis dengan cara menghitung skor yang diperoleh. Analisis skor yang digunakan yaitu analisis deskriptif yang digunakan untuk menghitung prosentase dari hasil angket yang akan diberikan untuk ahli media, ahli materi, angket respon guru kelas dan angket respon siswa dengan langkah-langkah sebagai berikut:

Tahap selanjutnya adalah perencanaan. perencanaan dilakukan untuk menyusun apa yang dipelukan melalui hasil proses pengumpuln data. Perencanaan ini adalah hal-hal yang mencakup merumuskan kemampuan, merumuskan tujuan khusus untuk menentukan urutan bahan, dan uji coba skala kecil. Hal yang sangat urgen dalam tahap ini adalah merumuskan tujuan khusus yang ingin dicapai oleh produk yang dikembangkan. Tujuan ini dimaksudkan untuk memberikan informasi yang tepat untuk mengembangkan program-program atau produk sehingga program atau produk yang diuji cobakan sesuai dengan tujuan khusus yang akan dicapai dalam penelitian pengembangan.

Tahap selanjutnya yaitu pengembangan draf produk. Pada tahap ini pengembangan meliputi kegiatan membuat dan mengembangkan bentuk awal produk media agar sesuai dengan tujuan materi pembelajaran yang sudah ditentukan. Desain media Gunungan yang dirancang peneliti berdasarkan buku guru dan buku siswa kurikulum 2013 yaitu pada tema 5 Permainan Tradisional Sub tema 2 Permainan Tradisional Pembelajaran 2, yang telah dirancang peneliti yaitu sebagai berikut : (1)Tahap ini dilakukan pengumpulan alat dan bahan kerangka Gunungan yang berkaitan dengan materi tema 5 Permainan tradisional sub tema 2 Permainan Tradisional Pembelajaran 2. Bahan-bahan pembelajaran yaitu buku Kurikulum 2013 tema 5 permainan tradisional sub tema 2 Permainan tradisional Pembelajaran 2 kelas III sekolah dasar. (2)Membuat Gunungan 
Pada tahap ini, peneliti peneliti membuat media Gunungan dengan alat dan bahan serta materi yang akan digunakan dalam pembelajaran. Tentunya menyesuaikan dengan materi pada tema 5 Permainan tradisional sub tema 2 Permainan Tradisional Pembelajaran 2. Dalam pembuatan media Gunungan ini langkah pertama yang peneliti lakukan adalah menyiapkan laptop yang akan digunakan untuk membuat desain kerangka gunungan terlebih dahulu. Desain ini dibuat menggunakan aplikasi corel draw. Setelah desain kerangka selesai dilanjutkan dengan melakukan desain gambar-gambar yang sesuai dengan materi tema 5 Permainan tradisional sub tema 2 Permainan Tradisional Pembelajaran 2. Setelah proses desain selesai, tahap yang dilakukan peneliti selanjutnya adalah mencetak desain yang sudah selesai. Desain di cetak menjadi MMT. Setelah proses pencetakan selesai peneliti juga membuat packaging yang digunakan sebagai wadah untuk meletakkan media MMT dan buku soal yang ada. Media gunungan ini juga disertai dengan buku soal sebagai pendampingnya. Langkah pertama yang dilakukan dalam membuat buku soal ini adalah tentunya peneliti sudah mempersiapkan membuat soal 45 soal untuk dijawab oleh pesera didik ketika permainan Gunungan dimainkan. Langkah selanjutnya yaitu guru mendesain background buku dengan animasi-animasi yang sesuai dengan materi yang disampaikan. Setelah mendesain background, peneliti lali meletakkan soal-soal tersebut di atas animasi yang telah dibuat. Setelah itu, proses yang terakhir adalah mencetak buku soal. Buku soal di cetak dengan menggunakan kertas ivori supaya buku ridak mudah lecek dan tidak mudah rusak. Alat-alat evaluasi atau instrumen validasi yang digunakan dalam pengembangan media gunungan yang meliputi angket ahli media validasi pertama, angket ahli materi validasi pertama, angket ahli materi validasi kedua, angket ahli materi validasi ketiga, angket respon guru kelas, angket respon siswa, RPP dan silabus kelas III A dan kelas III B di SD Tompomulyo 02.

Selanjutnya tahap yang dilakkan adalah uji coba lapangan awal. Uji coba lapangan awal dilakukan setelah melalui pengembangan draf produk yang sudah terlebh dahulu melalui tahap validasi olh beberapa validator. Tahap uji coba lapangan awal media pembelajaran gunungan ini dilakukan di Kelas III A dan Kelas III B SD Negeri Tompomulyo 02. Selanjutnya peneliti meminta guru kelas III A dan kelas III B di SD Negeri Tompomulyo 02 untuk mengisi angket respon guru terkait dengan media pembelajaran Gunungan yang sudah dibuat oleh peneliti.

Lalu tahap selanjutnya adalah tahap merevisi hasil uji coba. Setelah melakukan uji coba di dua sekolah dasar, peneliti dapat melihat hasil dari uji coba yang telah dilaksanakan. Peneliti dapat melakukan revisi produk bilamana produk yang di uji cobakan perlu untuk direvisi berdasarkan hasil angket yang telah disebar.

Namun, bila hasil angket yang telah disebar oleh peneliti mendapatkan hasil yang sangat layak maka produk media yang dikembangkan oleh peneliti yaitu media Gunungan sudah berada pada criteria yang telah diharapkan.

Tabel 1. Pedoman Pemberian Skor Ahli Media, Ahli Materi Angket dan Respon Guru Kelas

\begin{tabular}{lcc}
\hline & Keterangan & Skor \\
\hline SB (Sangat Baik) & \multicolumn{2}{c}{5} \\
B (Baik) & 4 \\
C (Cukup) & 3 \\
K (Kurang) & 2 \\
SK (Sangat Kurang) & 2 \\
\hline
\end{tabular}

Setelah itu, adalah tahap Produk media gunungan divalidasi oleh ahli materi kurikulum 2013 dan ahli meida pembelajaran. Angket validasi menggunakan skala likkert dengan rentang skor 1-4. Hasil validasi dihitung menggunakan rumus yaitu:

Persentase : $\frac{\text { Skor yang di dapat }}{\text { skor maksimal }} \times 100 \%$

Tabel 2. Kriteria Interpretasi Kelayakan Media

\begin{tabular}{cc}
\hline Penilaian & Kategori \\
\hline $0 \%-20 \%$ & Sangat tidak layak \\
$21 \%-40 \%$ & Tidak layak \\
$41 \%-60 \%$ & Cukup Layak \\
$61 \%-80 \%$ & Layak \\
\hline
\end{tabular}


Hasil validasi jika terdapat kesalahan, kekurangan, kritikan, dan saran selanjutnya dilakukan revisi. Produk media gunungan yang telah revisi dan dinyatakan layak maka dapat digunakan untuk uji coba produk. Penelitian akan dilakukan di SD N Tompomulyo 02 dengan subyek penelitian siswa kelas III. Instrumen penelitian terdiri dari observasi, pedoman wawancara, dan angket. Teknik pengumpulan dan analisis data menggunakan observasi keadaan sekolah, pembelajaran di kelas III, wawancara guru, angket guru dan siswa, serta angket validasi pakar ahli.

\section{ANALISIS DAN PEMBAHASAN}

Berdasarkan tahap awal yang dilakukan peneliti untuk mengetahui apa yang sedang dibutuhkan oleh guru dan siswa dalam pembelajaran serta akan menjadi langkah awal penelitian yang akan dilakukan peneliti yaitu mengenai media pembelajaran gunungan yang akan dikembangkan. Observasi yang dilakukan peneliti, terkait dengan proses pembelajaran dikelas III yang berjumlah 2 kelas, yaitu kelas III A dan kelas III B SD N Tompomulyo 02 yang berada di lingkup Desa Tompomulyo. Adapun dari kedua kelas III sekolah dasar yang menjadi subjek responden observasi oleh peneliti meliputi kelas III A dan kelas III B SD Negeri Tompomulyo 2. Dari hasil observasi tersebut diperoleh informasi bahwa proses pembelajaran penggunaan media masih kadang kala, dan itupun media yang digunakan adalah media yang sudah tersedia saja dari sekolah. Sehingga guru dan siswa membutuhkan media yang baru yang bisa lebih praktis untuk proses pembelajaran yang belajar dengan belajar dan bermain.

Dalam pengembangan media yang ditujukan untuk kelas III sekolah dasar tema 5 sub tema 2 pembelajaran 2 yaitu "permainan tradisional" perlu adanya tahap didapatkan kelayakan media. Kelayakan media gunungan didapatkan dari validator ahli media dan ahli materi pembelajaran.

Ahli media adalah bapak Rofian, S.Pd, M.Pd (Dosen Universitas PGRI Semarang). Sedangkan ahli materi pembelajaran adalah Ibu Anggun Dwi Setya P., M.Pd (Dosen Universitas PGRI Semarang). Untuk angket respon guru kelas dengan menerapkan pilihan jawaban yang meliputi ( $5=$ sangat baik), $(4=$ baik $)$, ( 3 = cukup), ( 2 = kurang), (1= sangat kurang), dalam bentuk skala likert sebagai bahan evaluasi layak dan tidaknya media gunungan yang dikembangkan oleh peneliti. Sedangkan angket respon siswa dengan menerapkan pilihan jawaban dua interval saja yaitu $(1=$ setuju $)$ dan $(0=$ tidak setuju).

Untuk megembangkan media pembelajaran yang dilakukan oleh peneliti adalah melakukan deskripsi perencanaan hasil pengembangan. Dalam melakukan deskripsi perencanaan hasil pengemangan dilakukan tahapan yaitu Perencanaan rancangan media gunungan, desain media awal, dan Validasi produk (validasi media dan validasi materi).

Perencanaan rancangan media gunungan ini dilakukan dengan menyusun komponen dan elemen. Media gunungan memiliki beberapa komponen dan elemen yang unik sehingga menjadikan desain tampilan media gunungan lebih menarik. Diantaranya gambar yang berbentuk kartun sehingga menarik perhatian siswa, terdapat gunungan yang dapat dilihat dan digunakan (kongkrit) dengan keadaan yang sebenarnya dan dapat dilipat, mudah disimpan, mudah bawa kemanapun dan tahan lama. Terdapat soal yang menarik setiap kotak gunungan. Tempat media gunungan juga sangat praktis dan mudah bawa kemanapun. Setelah perencanaan rancangan media gunungan, dilakukan tahap desain media awal. Desain awal dilakukan untuk mendesain media yang akan dikembangkan. Selain media pembelajarannya juga pengembangan disertai dengan buku langkah-langkah penggunaan media, kartu soal, serta penyajian media gunungan yang telah di kembangkan oleh peneliti terlihat menarik, rapih, praktis, serta aman digunakan ketika proses pembelajaran. Tahap desain media awal dilakukan dengan sekaligus melakukan proses validasi dengan validator ahli media dan validator ahli materi. Proses validasi dilakukan untuk memperaiki dan mengetahui seberapa layak media gunungan yang telah dikembangkan oleh peneliti. Apabila media dinatakan sangat layak oleh para validator ahli media dan validator ahli materi, maka media gunungan dapat digunakan untuk uji coba penelitian awal.

Produk Media Gunungan dinyatakan sangat layak digunakan dalam uji coba penelitian awal. berdasarkan hasil validasi pakar ahli yaitu : (1) Validasi Media Pembelajar. Validasi media oleh validator ahli tampilan yaitu bapak Rofian S.Pd., M.Pd. dosen Seni Rupa. Selain bapak Rofian S.Pd., M.Pd. sebagai validator ahli media adalah Ibu Muntasiroh, S.Pd. Ibu Retno S.Pd adalah guru kelas III B SD N Tompomulyo 02. Analisa hasil uji validasi dilakukan untuk memperoleh informasi dan hasil kelayakan dari media yang telah dikembangkan untuk digunakan pada penelitian di sekolah yang telah dituju. Hasil validasi media pertama kali diajukan pada ahli media tersebut memperoleh hasil persentase 80,8\% dengan kriteria layak, setelah validasi media pembelajaran telah selesai dilakukan revisi, maka media pembelajaran tersebut mendapatkan hasil presentase 95\% dengan kriteria sagat layak oleh ahli validasi 1 yaitu Bapak 
Rofian, S.Pd., M.Pd. serta dari ahli validasi 2 yaitu Ibu Muntasiroh, S.Pd mendapatkan presentase 96\% dengan kriteria sangat layak .

Tabel 3. Hasil validasi media oleh validator 1 dan 2

\begin{tabular}{llll}
\hline No. & Validator & Presentase & Kriteria \\
\hline 1. & Validator 1 & $95 \%$ & Sangat Layak \\
2. & Validator 2 & $96 \%$ & Sangat Layak \\
\hline
\end{tabular}

Dari hasil validasi media oleh validator 1 dan 2 mendapatkan skor presentase total 89,06\% dengan kriteria sangat layak. Sehingga media sangat layak dan dapat digunakan dalam pembelajaran. Materi dalam pengembangan media gunungan pada pemmbelajaran tematik tema permainan tradisional kelas III Sekolah dasar ini ada dua orang ahli, yaitu ibu Anggun Dwi Setya P., S.Pd., M.Pd. (dosen Universitas PGRI Semarang) dan Ibu Retno, S.Pd. (guru kelas III A SD N Tompomulyo 02). Validasi materi dengan ibu Anggun Dwi Setya P., S.Pd., M.Pd. (dosen Universitas PGRI Semarang) dilakukan dua tahap, yaitu tahap pertama dan tahap kedua. Sedangkan validasi materi dengan ibu Retno S.Pd (Guru Kelas III A SD N Tompomulyo 02) dilakukan satu kali.

Dari hasil analisis ahli validasi materi Ibu Anggun Dwi Setya P.,S.Pd.,M.Pd. (dosen Universitas PGRI Semarang) pada tahap pertama diperoleh hasil persentase validasi sebesar $80,95 \%$ dengan kriteria layak. Setelah dilakukan revisi dalam validasi materi, hasil persentase yang diperoleh dari dosen validasi 1 Ibu Anggun Dwi Setya P.,S.Pd.,M.Pd. yaitu 85,71\% dengan kriteria sangat layak. Dan hasil persentase validasi dari validator 2 yaitu Ibu Retno, S.Pd mendapatkan 100\% dengan kriteria sangat layak.

Tabel 4. Hasil validasi materi oleh validator 1 dan 2

\begin{tabular}{llll}
\hline No. & Validator & Presentase & Kriteria \\
\hline 1. & Validator 1 & $85,71 \%$ & Sangat Layak \\
2. & Validator 2 & $100 \%$ & Sangat Layak \\
\hline
\end{tabular}

Dilihat dari hasil validasi materi oleh validator 1 dan 2 mendapatkan skor presentase total 88,88 \% dengan kriteria sangat layak. Sehingga materi layak dan dapat digunakan sebagai bahan ajar pembelajaan. (2) Hasil angket respon guru kelas III A dan III B mendapatkan hasil kriteria sangat layak yaitu 100\%.

Tabel 5. Hasil Angket Respon Guru Kelas Uji Coba Lapangan Awal

\begin{tabular}{llll}
\hline No. & Guru Kelas & Presentase & Kriteria \\
\hline 1. & Guru Kelas III A & $100 \%$ & Sangat Layak \\
2. & Guru Kelas III B & $100 \%$ & Sangat Layak \\
\hline
\end{tabular}

Dilihat dari hasil angket respon guru kelas III A dan guru kelas III B mendapatkan skor presentase total $100 \%$ dengan kriteria sangat layak. Selain respon guru, respon siswa juga menjadi tolak ukur keberhasilan media ini.

Dalam penelitian kali ini mendapatkan hasil respon siswa kelas III A sebesar 98,94\% dengan kriteria sangat layak dan pada kelas III B memperoleh hasil respon siswa sebesar 98,66\%. (3) Nilai hasil belajar siswa kelas III A dan kelas III di atas KKM. Kelas III A memperoleh nilai autentik dengan rata-rata nilai akhir 89,13 dan kelas III B memperoleh nilai autentik dengan rata-rata nilai akhir 88,81.

Tabel 6. Rata-rata Penilalaian Autentik Kelas III A dan Kelas III B Uji Coba Lapangan Awal

\begin{tabular}{ccccc}
\hline \multirow{2}{*}{ No } & Kelas & Sikap & $\begin{array}{c}\text { Penilaian } \\
\text { Pengetahuan }\end{array}$ & Ketrampilan \\
\hline 1. & Kelas III A & 87,50 & 97,63 & 81,57 \\
2. & Kelas III B & 86,80 & 80,50 & 97,22 \\
& Rata-rata & 87,15 & 89,06 & 89,39 \\
\hline
\end{tabular}

Dilihat dari hasil angket respon kelas kelas III A sebanyak 19 siswa dan guru kelas III B sebanyak 18 siswa dengan total siswa dalam kelas III A dan III B adalah 37 siswa mendapatkan rata-rata nilai sikap 87,15 , rata-rata nilai pengetahuan 89,06 , dan rata-rata nilai keterampilan 89,39. 


\section{KESIMPULAN}

Berdasarkan dari hasil penelitian dan pengembangan pada penelitian pengembangan media gunungan, maka dapat diambil simpulan yaitu: (1) Media layak digunakan karena mendapatkan hasil sangat layak sesuai dengan hasil validasi ahli materi dan hasil validasi ahli media. (2) Media layak digunakan karena mendapat hasil sesuai dengan hasil angket respon guru kelas mendapatkan persentase skor total sebesar $100 \%$ dengan kriteria sangat layak dan hasil angket respon siswa mendapatkan persentase skor total sebesar 98,94\% dengan kriteria sangat layak. (3) Media layak digunakan karena 80\% siswa memperoleh ketuntasan dalam aspek kognitif, afektif, dan psikomotorik. Aspek sikap mendapat skor total 87,15\%, aspek pengetahuan mendapat skor 89,06\%, dan aspek ketrampilan mendapat skor $89,39 \%$. Dari hasil yang diperoleh tersebut media gunungan layak digunakan untuk pembelajaran tematik tema permainan tradisional di kelas III Sekolah Dasare.

Berdasarkan temuan penelitian, saran-saran yang perlu disampaikan adalah Berdasarkan dari hasil penelitian dan pengembangan yang dilakukan oleh peneliti, maka saran yang dapat diberikan terkait dengan hasil penelitian dan pengembangan media gunungan yaitu, (1) Dalam pembelajaran, penggunaan media pembelajaran berpengaruh terhadap peningkatan nilai kognitif, afektif dan psikomotorik siswa. Sehingga dalam pembelajaran penggunaan media pembelajaran sangat diperlukan. (2) Sejalan dengan pengembangan ini, diharapkan peneliti selanjutnya dapat mengembangkan media gunungan dalam pembelajaran sepaya media pembelajaran lebih inovatif lagi.

\section{DAFTAR PUSTAKA}

Andriani, T., 2012. Permainan tradisional dalam membentuk karakter anak usia dini. Sosial Budaya, Vol. 9, No. 1, pp.121-136.

Cahyasari, Astrie. 2016. Pengaruh Permainan Tradisional Engklek Terhadap Konsentrasi Anak Attention Deficit Hyperactivity Disorder (Adhd). Universitas Muhammadiyah Malang. Diakses Pada Tanggal 29 September 2018.

Hidayat, D., 2013. Permainan tradisional dan kearifan lokal kampung dukuh garut selatan Jawa Barat. Academica: Majalah Ilmu Sosial dan Ilmu Politik, Vol. 5, No. 2)

Jannah, Siti Nur. 2016. Pengembangan Media Engklek Tematik Tema Cita-Citaku Sebagai Pendukung Kompetensi Berimbang Pada Siswa Kelas IV SD Negeri Desa Raci Kec. Batangan Kab. Pati. Universitas Pgri Semarang.

Khasanah, I., Prasetyo, A. and Rakhmawati, E., 2011. Permainan tradisional sebagai media stimulasi aspek perkembangan anak usia dini. PAUDIA: JURNAL PENELITIAN DALAM BIDANG PENDIDIKAN ANAK USIA DINI, Vol. 1, No.1.

Mulyasa. 2016. Pengembangan dan Implementasi Kurikulum 2013. Bandung. PT Remaja Rosdakarya.

Nara, Hartini dan Eveline Siregar. 2014. Teori Belajar dan Pembelajaran. Bogor: Ghalia Indonesia.

Pribadi, Benny A. 2010. Model desain system pembelajaran. Jakarta. PT Dian Rakyat.

Arsyad, Azhar. 2014. Media Pembelajaran. Jakarta: PT Raja Grafindo Persada.

Daryanto. 2014. Pembelajaran Tematik, Terpadu, Terintegrasi (kurikulum 2013). Yogyakarta: Gava Media.

Sugiyono. 2015. Metode Penelitian Pendidikan (Pendekatan kuantitatif, kualitatif, dan R \& D). Bandung: Alfabeta

Munawaroh, Hidayati. 2017. Pengembangan Model Pembelajaran dengan Permainan Tradisional Engklek Sebagai Sarana Stimulasi Perkembangan Anak Usia Dini. Universitas Sains Al-Qur'an Wonosobo. Diakses pada tanggal 29 September 2018.

Khasanah, dkk. 2011. Permainan Tradisional Sebagai Media Stimulasi Aspek

Perkembangan Anak Usia Dini. PAUDIA Universitas PGRI Searang . Diakses pada tanggal 29 September 2018.

Undang-Undang Republik Indonesia Nomor 20 Tahun 2003.Sistem Pendidikan Nasional.Jakarta. 
Putri, ati bahiyati utami dan hasyim, noor. 2017. Upaya Melestarikan Permainan Tradisional Engklek Melalui Teknologi Digital Interaktif. Universitas Dian Nuswantoro.

Putri, dkk. Mengenalkan Permainan Tradisional Engklek Melalui Teknologi Digital. Universitas Dian Nuswantoro. Diakses pada tanggal 29 September 2018

Nugraha, Hafizhah Sri. Kelayakan Media Permainan Engklek Sebagai Media Pembelajaran Pada

Materi Sistem Pencernaan Makanan. UNESA. Diakses pada tanggal 3 Januari 2019

Mashudi, Putra Mardhani. 2016. Pengembangan model Permainan ngklek menggunakan musik instrumental unuk pembelajaran gerak dasar melompat pada siswa kelas V MI Al Iman Banaran Kecamatan Gunung Pati Jawa Tengah. Universitas Negeri Semarang. Diakses pada tanggal 20 Oktober 2018

Ridwan, Daenuri. 2015. Pengaruh Metode Permainan Tradisional Engklek Terhadap Hasil Belajar Siswa pada Mata Pelajaran IPS Kelas III SD I Al-Falah Pagi. Universitas Islam Negeri Syarif Hidayatullah. Diakses pada tanggal 2 November 2018 